DIGITALCOMMONS

—@WAYNESTATE -

Journal of Modern Applied Statistical

Methods

Volume 12 | Issue 1

Article 6

$5-1-2013$

\title{
Conceptual Distinction between the Critical $p$ Value and the Type I Error Rate in Permutation Testing: Author Response to Peer Comments
}

Richard B. Anderson

Bowling Green State University

Follow this and additional works at: http://digitalcommons.wayne.edu/jmasm

Part of the Applied Statistics Commons, Social and Behavioral Sciences Commons, and the Statistical Theory Commons

\section{Recommended Citation}

Anderson, Richard B. (2013) "Conceptual Distinction between the Critical $p$ Value and the Type I Error Rate in Permutation Testing: Author Response to Peer Comments," Journal of Modern Applied Statistical Methods: Vol. 12 : Iss. 1 , Article 6.

DOI: $10.22237 /$ jmasm/1367381100

Available at: http://digitalcommons.wayne.edu/jmasm/vol12/iss1/6

This Invited Debate is brought to you for free and open access by the Open Access Journals at DigitalCommons@WayneState. It has been accepted for inclusion in Journal of Modern Applied Statistical Methods by an authorized editor of DigitalCommons@WayneState. 


\section{Conceptual Distinction between the Critical $p$ Value and the Type I Error Rate in Permutation Testing: Author Response to Peer Comments}

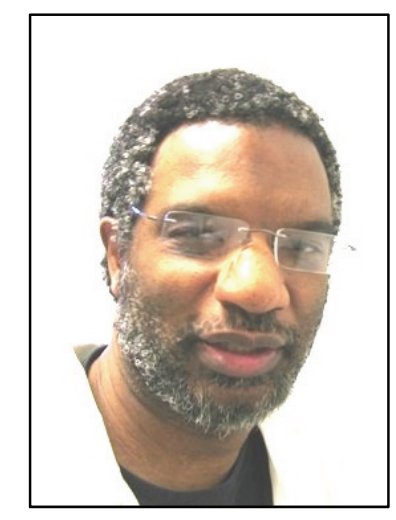

Richard B. Anderson

Bowling Green State University

Bowling Green, $\mathrm{OH}$

Richard Anderson responds to comments regarding his target article Conceptual Distinction between the Critical $p$ Value and the Type I Error Rate in Permutation Testing.

Key words: Statistics, null hypothesis, non-parametric, permutation test, exchangeability; Type I error; validity.

\section{Response}

Some of the replies to my article, Conceptual Distinction between the Critical $p$ Value and the Type I Error Rate in Permutation Testing, have focused on what is called an exchangeability requirement, and on the question of whether previous evaluations of permutation test validity

Richard Anderson is an Associate Professor of Psychology in the Department of Psychology. His research interests include topics in judgment, decision-making, reasoning, memory, statistical cognition, and statistical methods. He teaches courses in cognition, statistics, and research methods and holds memberships in the Psychonomic Society and the Cognitive Science Society. Email him at: randers@bgsu.edu. have violated exchangeability. It should be clarified that the aim was not to critique previous analyses on grounds of exchangeability violation: The purpose was to address exchangeability as a characteristic of how the permutation test's null hypothesis is formulated. No claims were advanced concerning the idea that exchangeability is an assumption to be met or violated by a given dataset. Instead, the central thesis was that when a significance criterion is adopted, for example 0.05, for rejecting the null hypothesis of random coupling of data points to condition labels, that 0.05 is not a Type I error probability. 


\section{RICHARD ANDERSON RESPONSE TO PEER COMMENTS}

\section{References}

Anderson, R. B. (2013). Conceptual Distinction between the Critical $p$ Value and the Type I Error Rate in Permutation Testing. Journal of Modern Applied Statistical Methods, 12(1), 2-8.

Good, P. (2013). p-Values versus Significance Levels. Journal of Modern Applied Statistical Methods, 12(1), 9-10.
Manly, B. (2013). Randomization Test $p$-Values versus Significance Levels. Journal of Modern Applied Statistical Methods, 12(1), 18.

Pesarin, F., \& Bonnini, S. (2013). A Response to Richard Anderson's Conceptual Distinction between the Critical $p$ value and Type I Error Rate in Permutation Testing. Journal of Modern Applied Statistical Methods, 12(1), 11-17. 